\title{
The Improving Online and Offline Activities through Blended Learning Model in Class
}

\author{
Dedy Irawan ${ }^{1}$, Cicih Wiarsih ${ }^{2}$, Badarudin $^{3}$, Ninda Nur Afifah ${ }^{4}$ \\ $\left\{\right.$ dedy.pgsd@gmail.com¹ ${ }^{1}$, cicihwiarsih.umpwt@gmail.com² \\ badarudinbdg@gmail.com ${ }^{3}$, nindanurafifah17@gmail.com ${ }^{4}$ \} \\ 1,2,3,4 Universitas Muhammadiyah Purwokerto
}

\begin{abstract}
During the COVID-19 pandemic, Indonesian Ministry of Education and Culture released policy namely closed school and changed teaching and learning process using online learning system. This study used Blanded Learning model which combined 2 learning that were offline and online learning. This classroom action research aimed to improve learning activities by online and offline for students. This Study was carried out in May 2021 in V Class SD Muhammadiyah Purwokerto. This Study was Classroom Action research with 2 cycles consist of 2 meeting in a cycle. This study refered to Kemmis \& Mc. Taggart that were planning, implementing actions, observing, and reflecting. The subjects of this study were 23 students consist of 16 male students and 7 female students. The instruments used were students and teachers observation sheet, performance assessment of oral reading comprehension, and face-to-face and online evaluation sheets of students. The results of this study indicated improvement in face-toface activities in the cycle I reaching $44.44 \%$ learning completeness and in the cycle II increased to $88.8 \%$, meanwhile improvement online activities in cycle I reaching $57,14 \%$ and in cycle II increased to $85,71 \%$. It could be concluded that the implementing of Blended Learning model could improve online and offline learning activities for students.
\end{abstract}

Keywords: Covid-19 Pandemic, Online and Offline Activities, Blended Learning Model

\section{Introduction}

Education is the important thing to improve the intelligence quality of the Indonesian nation. According to Supardi, Education is defined as conscious effort which given to students from educators in order to achieve optimal abilities. Education for humans is an absolute need which should be full filed throughout life [1]. Without education, humans cannot live and thrive in line with the aspiration to live in prosperity. One of the important components in Indonesian education is teacher.

Teachers play a role in efforts to improve the quality of Indonesian education through the learning process in schools. According to Syah, learning process in school is the best public policy tool as effort to improve knowledge and skill [2]. School is interaction media between students and teachers to improve intelligence, skill, and affection ability.

The spread of the Covid-19 pandemic has presented many challenges for educational institutions in Indonesia. According to Siahaan, through the limitation of interaction, Ministry of Education in Indonesia also release policy that is closed school and changed Teaching and Learning Process to online or distance learning [3]. By using online system or distance learning, the learning does not take place in a room and there is no face to face interaction directly between students and teachers. This distance learning is conduct at home by utilizing 
internet technology which can help students for study. Distance learning make students cannot comprehend reading skills of Indonesian subjects in learning process which given by the teacher optimally because of the lack of face to face time and the low reading interest of students in reading.

According to Basar, students who less able comprehend reading in Indonesia subject which has presented through online media by teacher, internet networks that are sometimes disrupted and lack of use of online learning media [4]. So, the learning delivered by teachers is not optimal. Media used by teacher to conduct distance learning such as Google Classroom, Zoom and Whatsapp Group, but the students never open the platform. Then the teacher get difficulties to know whether the students comprehend the concept of reading skill in Indonesian subject properly or not. It will make the students' reading interest is low.

Regarding the education quality which still low because of the distance learning which is currently being implemented by the government due to the Covid-19 virus. In this case, the problem is the lack of the students' comprehend to concept Indonesian itself. One measure of success in learning science concept is it can be understood by students. According to Kusmawati, students is said comprehend a concept which given in learning process if they can tell ad explain a concept which is get based on their own words not just memorizing [5]. By re-explaining the material or the concept which explain by teacher use their own thoughts it can be said the comprehension which they achieve is good. Besides being able to understand the concept of Indonesian, students are expected to increase reading interest in students in learning.

Based on the initial observation and interview which conducted on November 27, 2020 with teacher of $5^{\text {th }}$ Grade in SD Muhammadiyah Purwokerto stated with Covid 19 pandemic so the learning was conducted online for students. It was carried out based on a circular from the Head of Banyumas Education and Culture Office No. 422.4/2177/2020 regarding efforts to prevent the spread of the corona virus (COVID-19) so that learning is carried out at home, with this the school implements an online learning system, so that in its implementation there must be a role from parents to accompany students to study at home. The condition shows there are obstacles which often face by teachers in the distance learning process, namely students have difficulty understanding various reading contents or texts so it affects the low reading skills which presented by the teacher through the platform, cannot do the task fully well and are indisciplined in collecting Duty.

Indonesian learning is focused on four aspects of language skills according to Dalman in Budianti \& Damayanti, such as listening skills, speaking skills, reading and writing skills. The four aspects of these skills are interrelated with one another. Skilled in language means skilled in listening, speaking, reading and writing in good and correct language. Language skills, especially reading skills, are skills that are needed by students. According to Dewi, reading skills are one of the successes of students in achieving progress. With adequate reading skills, students will find it easier to explore information from various written sources [6]. Schools have the opportunity to fosters students' reading culture, nowdays schools are hampered to carry out the learning process takes place at school

This is due to the Covid-19 pandemic in the lives of the surrounding community. Nowadays education study from home or study at their own home. When is being implemented or distance learning. When study from home or distance learning was implemented, most students spend their time playing rather than reading. Some of the problem, the teacher of $5^{\text {th }}$ grade had tried students understand the contents of the reading text by repeateing teaching until they really understand. Teacher sometime explained some item 
related reading skill, but now students is not focus because in distance learning the students preferred to play and play games on mobile phones.

Form the condition that had been explained so it is necessary to apply a learning strategy which before had been discussed with the school to find solution from the problem. Based on the discussion, the result obtained by implementing strategies, one of them is Blended Learning Strategy.

According to Istiningsih and Hasbullah, blended learning is process of uniting various learning method which can be achieved by combining virtual and physical sources [7]. By combining some methods in learning to achieve the expected learning outcomes. Blended Learning can be used as alternative strategy in learning strategy due to able to combine learning activities in class with online learning towards independences in learning. Online learning has advantage in the wealth of learning resources provided, where teachers and students can achieve a wide range of learning resources. In addition to having advantages, this learning also has a weakness, namely there is no direct interaction between teachers and students. Based on the problems and literature review, a research design with the CAR design will be carried out with the title "Efforts to Improve Online and Offline Activities Through Blended Learning Models in Class V SD Muhammadiyah Purwokerto". Through this research, it is hoped that the understanding of the concept of aspects of reading skills in students will improve.

\section{Research Methodology}

This study used Classroom Action Research (CAR). Classroom Action Research was conducted on 5 May until 27 May 2021 in The Academic Year 2020/2021 at SD Muhammadiyah Purwokerto. The subjects of this study were students' V Class at SD Muhammadiyah Purwokerto consists of 16 male students and 7 female students, so the total were 23 students. But to offline study was followed by 9 students consist of 5 female students and 4 male students. Then, for the online research followed by 14 students of $5 \mathrm{~A}$.

This Classroom Action Research was designed by 2 cycle which each cycle consists of 2 meeting to improve understanding of the material and the activeness students in Blended Learning model. The flow of this class research used the Kemmis and Mc. Taggart in Kusumah and Dwitagama. Each cycle consists of planning (planning), action (action), observation (observation), and reflection (reflection). The instruments in this study were teacher observation sheets, student activity observation sheets, concept understanding reading skills tests, interview test sheets and documentation.

\section{Result and Discussion}

This study conducted in 2 cycle, namely cycle I and cycle II. Each cycle consists of 2 times meeting, each meeting took 70 minutes or $2 \times 35$ minutes. The study carried out in cycle I that was 5 May 2021 until 8 May 2021. This CAR was conducted by V Class teacher, as executor of the action, namely Rusdiyanto, S.Pd, the researcher as observer 1 in charge of observing the activities of the teacher, observer 2 in charge of observing the activities of the students. , and observer 3 who was in charge of documenting every learning activity in the classroom.

Each cycle consists of several stages, namely the stages of planning, action, observation, and reflection. Each action was observed to determine the activities of the teacher 
and the activities of students in face-to-face and online learning. The following are the results of student activities online and offline:

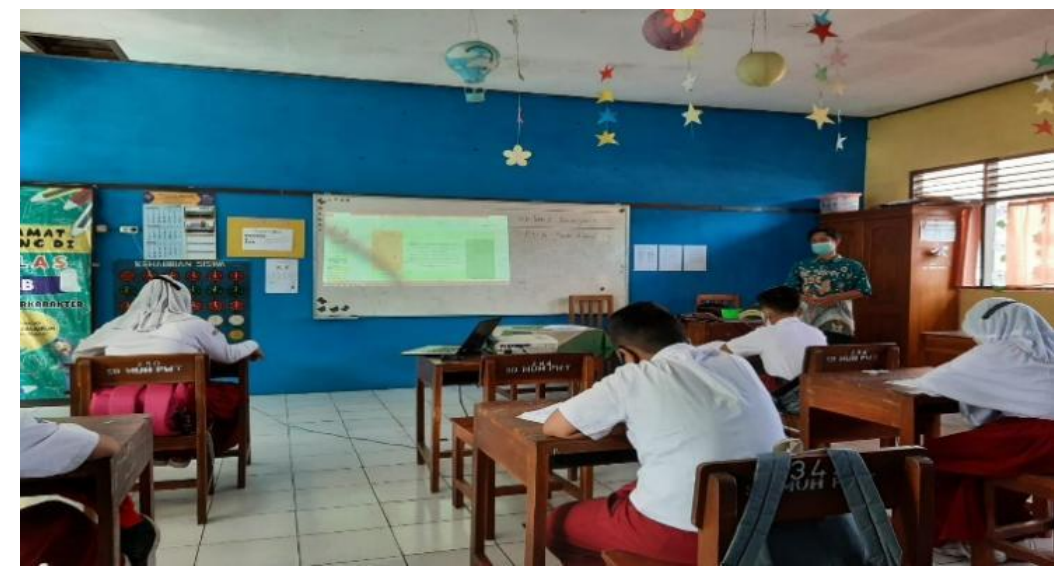

Figure 1. Teacher explaine the material using powerpoint

Figure 1 shows that the teacher is explaining the meaning of advertising. After the teacher explains the advertising material, then the teacher asks students to form several groups and do evaluation items of oral reading comprehension (worksheet). The teacher gives time to group and do that items. The set time has been completed, then the teacher asks students to come forward and read the answers that have been discussed with the group. The teacher gives assignments to each group to read the results of the discussion and understand the contents of the reading. When students take turns reading, the teacher observes students activity, there are students who are actively taking turns reading with their groups, but there are also groups who are passive because they just focus at the reading without any discussion to determine the answers in the worksheet.

The main activity in online learning, the teacher explained material about the meaning of advertising, the characteristics of advertisements and advertising language from print media or electronic media assisted by videoslide media which contains the main points of material about advertising. The teacher provided advertising material that has been uploaded to YouTube and shares the link via the WhatsApp group platform. The teacher provided material and gives time for students to understand the material first. The teacher asked the students whether they understand or not releted the material given by the teacher, if the students have understand, the teacher gave a re-understanding of the material so that participants are not confused. 


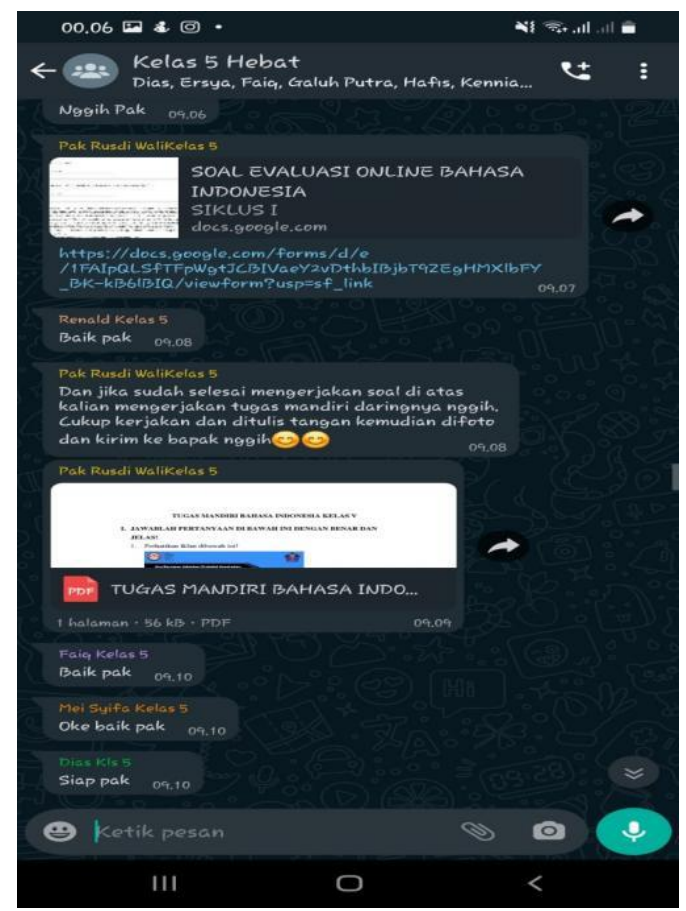

Figure 2. Teacher give online evaluation items and independent assignment to students.

Then, teacher distributed advertising material Theme $9^{\text {th }}$ The Thing surrounding of Us through Video slide media which had be uploaded to Youtube, and teacher divided material link to Whatsapp group which will be studied by students. In each cycle, the teacher gives an evaluation question of understanding Indonesian language comprehension aspects of reading skills through the Google Forms platform, which aims to measure students' understanding in obtaining material that has been taught by the teacher online.

The result of evaluation or students' achievement can be assessed using evaluation test which be done in each meeting. This achievement include understanding test of students that is online and face to face comprehension evaluation. Face to face evaluation items can be conducted in subject of $\mathrm{V}$ class and online be conducted through platform which used by teacher to give learning material when distance learning. Beside of that, students also given independent assignment to measure how far the students can do their assignment. The results of face-to-face evaluation of students' learning achievement in cycle I can be explained in table 1 below:

Table 1. The result of Face to Face Evaluation Achievement Cycle I and II

\begin{tabular}{lcc}
\hline \multicolumn{1}{c}{ Indicator } & Cycle I & Cycle II \\
Number of Students & 9 & 9 \\
KKM & 66 & 66 \\
The Highes Score & 76 & 92 \\
The Lowest Score & 44 & 64 \\
Number of Completed & 5 & 1 \\
Number of Not Complete & 4 & 8 \\
\hline
\end{tabular}


Based on the table 1 above, there were improve the learning achievement, from 63.1 to 79.7. There also improvement on learning completeness from Good Enough to Very Good criteria.

Tabel 2. The result of Online Evaluation Achievement During CAR

\begin{tabular}{lcc}
\hline \multicolumn{1}{c}{ Indicator } & Cycle I & Cycle II \\
\hline Number of Students & 14 & 14 \\
\hline KKM & 66 & 66 \\
\hline The Highes Score & 84 & 92 \\
\hline The Lowest Score & 48 & 60 \\
\hline Numberof Completed Students & 8 & 12 \\
\hline $\begin{array}{l}\text { Number of Not Complete } \\
\text { Students }\end{array}$ & 6 & 2 \\
\hline
\end{tabular}

Based on table 2 above, there were increasing of the average online evaluation learning achievement of students from 67.74 to 79.4 . Besides, there were improving of mastery learning from good to very good criteria.

Based on the activities of students, it can be proven that students have great attention in learning through the blended learning model assisted by powerpoint and video slide media in printed media advertising materials and electronic media through a reading text. The results of student learning achievement increase because students are more skilled in reading so that it is easier for students to understand a reading that is asked on worksheet, face-to-face and online evaluation questions, oral reading questions, and online independent assignments. The blended learning learning model assisted by powerpoint media can improve reading comprehension skills because in the learning process the model emphasizes reading activities. This is in line with research by Banditvilai which that the learning strategy is appropriate for future learning because it combines virtual and face-to-face learning, especially in language learning skills [8-9].

\section{Conclusions}

According the results of Classroom Action Research by implementing Blended Learning model with power point and video slide media on advertising materials and the content of advertising information from print or electronic in Indonesian subject to improve aspects of reading comprehension skills of $\mathrm{V}$ Grade at SD Muhammadiyah Purwokerto can be concluded that the result of this study shows there is improvement face to face activities in the Cycle I reaching 44,44\% learning completeness and in the cycle II it increase to $88,8 \%$, mainwhile improvement online activities in cycle I reaching $57,14 \%$ and in cycle II increased to $85,71 \%$. It could be concluded that the implementing of Blended Learning model could improve online and offline learning activities for students.

\section{Acknowledgements}

This study can be carried out well because of the help from various parties, for that researcher woud like to thank to Headmaster of SD Muhammadiyah Purwokerto, teacher of V Class, and all of V Grade students who have gave good cooperation in this study. 


\section{References}

[1] Supardi US. Arah pendidikan di Indonesia dalam tataran kebijakan dan implementasi. Formatif: Jurnal Ilmiah Pendidikan MIPA. 2015 Aug 5;2(2).

[2] Syah RH. The Impact of Covid-19 on Education in Indonesia: Schools, Skills, and Learning Processes. SALAM J Sos dan Budaya Syar-i. 2020;7:395.

[3] Siahaan M. Dampak pandemi Covid-19 terhadap dunia pendidikan. Dampak Pandemi Covid-19 Terhadap Dunia Pendidikan. 2020 May 1;20(2).

[4] Basar AM. Problematika Pembelajaran Jarak Jauh Pada Masa Pandemi Covid19:(Studi Kasus di SMPIT Nurul Fajri-Cikarang Barat-Bekasi). Edunesia: Jurnal Ilmiah Pendidikan. 2021 Jan 1;2(1):208-18.

[5] Kusmawati L. PENINGKATAN KEMAMPUAN PEMAHAMAN KONSEP PERKALIAN MELALUI PENDEKATAN PEMBELAJARAN KONSTRUKTIVISME PEMBELAJARAN MATEMATIKA DI KELAS 3 SDN CIBADUYUT 4. Didaktik: Jurnal Ilmiah PGSD STKIP Subang. 2016 Jun 30;1(2):26271.

[6] Dewi CA. Penerapan Strategi SQ3R Untuk Meningkatkan Keterampilan Membaca Pemahaman di Sekolah Dasar. Jurnal Penelitian Pendidikan Guru Sekolah Dasar. 2013 Jun 11;1(2):1-0.

[7] Istiningsih $\mathrm{S}$, Hasbullah H. Blended learning, trend strategi pembelajaran masa depan. Jurnal Elemen. 2015 Mar 13;1(1):49-56. Kusumah, W., \& D. Dwitagama. (2010). Mengenal Penelitian Tindakan Kelas. Jakarta: Indeks.

[8] Banditvilai C. Enhancing students language skills through blended learning. Electronic Journal of e-Learning. 2016 Jul 1;14(3): 223-232.

[9] Mukhasin M, Andriani A. The Influence of Used WhatsApp Group in Online Learning to Student Discipline at Elementary School. Dinamika Jurnal Ilmiah Pendidikan Dasar. 2021 Sep 22;13(2):76-8. 